Adji, T.N., Nurjani, E.M., Wicaksono, D., 2014, Zonasi Potensi Airtanah Dengan Menggunakan Beberapa Parameter Lapangan dan Pendekatan SIG di Daerah Kepesisiran, Hibah Sekolah Vokasi UGM, 2014

\title{
Zonasi Potensi Airtanah Dengan Menggunakan Beberapa Parameter Lapangan dan Pendekatan SIG di Daerah Kepesisiran
}

Oleh:

\section{TJAHYO NUGROHO ADJI EMILYA NURJANI DHONI WICAKSONO}




\section{LAPORAN AKHIR PENELITIAN}

Zonasi Potensi Airtanah Dengan Menggunakan Beberapa Parameter

Lapangan dan Pendekatan SIG di Daerah Kepesisiran

Groundwater Potential Zonation by Using Several Field Parameters and a GIS Approach in a Coastal Area

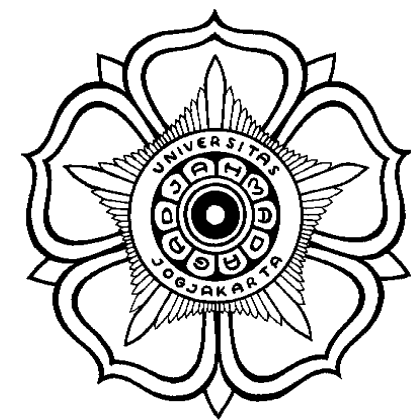

TJAHYO NUGROHO ADJI

EMILYA NURJANI

DHONI WICAKSONO

DILAKSANAKAN ATAS BIAYA DANA MASYARAKAT

BERDASAR KONTRAK NO: UGM/SV/1175.100/III/2014

SEKOLAH VOKASI

UNIVERSITAS GADJAH MADA

YOGYAKARTA

2014 


\section{HALAMAN PENGESAHAN \\ LAPORAN PENELITIAN SEKOLAH VOKASI UGM 2014}

\begin{tabular}{|c|c|c|c|}
\hline \multirow[t]{3}{*}{1.} & \multicolumn{2}{|c|}{ a. Judul Penelitian } & $\begin{array}{l}\text { Zonasi Potensi Airtanah Dengan Menggunakan Beberapa } \\
\text { Parameter Lapangan dan Pendekatan SIG di Daerah } \\
\text { Kepesisiran }\end{array}$ \\
\hline & \multicolumn{2}{|c|}{ b. Bidang Ilmu } & Teknologi Kebumian \\
\hline & \multicolumn{2}{|c|}{ c. Macam Penelitian } & Terapan \\
\hline \multirow[t]{7}{*}{2.} & \multicolumn{2}{|c|}{ Peneliti Utama } & \\
\hline & a. & Nama Lengkap & Dr. Tjahyo Nugroho Adji, S.Si,M.Sc.Tech \\
\hline & b. & Jenis kelamin & Laki-laki \\
\hline & c. & NIP & 197201281998031001 \\
\hline & d. & Jabatan Fungsional & Lektor Kepala \\
\hline & e. & Prodi & Penginderaan Jauh dan Sistem Informasi Geografi \\
\hline & f. & HP/E-mail & 08122967492/adji@geo.ugm.ac.id \\
\hline \multirow[t]{7}{*}{3.} & \multicolumn{2}{|c|}{ Peneliti Kedua } & \\
\hline & a. & Nama Lengkap & Emilya Nurjani, S.Si, M.Si \\
\hline & b. & Jenis kelamin & Perempuan \\
\hline & c. & NIP & 197110071998032001 \\
\hline & d. & Jabatan Fungsional & Lektor \\
\hline & e. & Prodi & Penginderaan Jauh dan Sistem Informasi Geografi \\
\hline & f. & HP/E-mail & 081328819400/n_emilya@geo.ugm.ac.id \\
\hline 4. & \multicolumn{2}{|c|}{ Jumlah anggota peneliti } & 1 \\
\hline 5. & \multicolumn{2}{|c|}{ Lokasi Penelitian } & sebagian daerah kepesisiran Parangtritis, DIY \\
\hline 6. & \multicolumn{2}{|c|}{ Kerjasama dengan institusi lain } & - \\
\hline 7. & \multicolumn{2}{|c|}{ Jangka waktu } & 8 (delapan) bulan, 1 Maret 2014 s.d. 31 Oktober 2014 \\
\hline 8 & \multicolumn{2}{|c|}{ Biaya yang disetujui } & Rp. 10.000.000,- (sepuluh juta rupiah) \\
\hline
\end{tabular}

Menyetujui,

Ketua Program D3 PJSIG

Taufik Hery Purwanto, SSi, MSi. NIP. 196804011997021001
Yogyakarta, 25 November 2014

Peneliti Utama

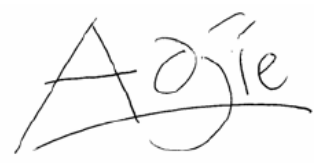

Dr. Tjahyo N. Adji, MSc.Tech NIP. 197201281998031001

Menyetujui, Direktur Sekolah Vokasi

Universitas Gadjah Mada

Ir. Hotma Prawoto Sulistiyadi, M.T.

NIP. 195603081985031001 


\section{INTISARI}

Sebuah studi kasus telah dilakukan untuk membuat zona potensi airtanah di daerah sekitar Pantai Parangtritis, Provinsi DIY. Tujuan dari penelitian adalah untuk untuk memetakan zona potensi airtanah berdasarkan parameter airtanah yang dapat disurvei di lapangan pada suatu daerah yang memiliki variasi bentuklahan yang beragam. Interpretasi sebaran bentuklahan dimulai dengan menyiapkan data pendukung seperti Peta Rupa Bumi Indonesia yang berisi informasi garis kontur dan data penggunaan lahan data, peta geologi regional untuk mengetahui kondisi litologi dan struktur geologi, data tanah, iklim, dan data hidrologis awal. Penentuan satuan bentuk lahan dilakukan secara manual melalui interpretasi visual dari citra Digital Landsat $\mathrm{ETM}^{+}$dengan beberapa kunci interpretasi yang diperoleh dari data sekunder dan disurvei di lapangan. Selanjutnya dilakukan pengukuran parameter lapangan potensi airtanah yaitu (a) kedalaman muka airtanah, (b) ketebalan akuifer, dan (c) Daya Hantar Listrik (DHL) yang mewakili kualitas airtanah. Zonasi potensi airtanah diperoleh dengan melakukan overlay semua parameter lapangan airtanah dengan metode overlay tertimbang menggunakan alat analisis spasial Sistem Informasi Geografi (SIG) pada perangkat lunak ArcGIS 9.2. Pada proses overlay tertimbang, peringkat yang dihasilkan untuk setiap parameter individu pada masing-masing parameter lapangan airtanah dibobot berdasarkan tingkat pengaruh yang mereka miliki terhadap potensi airtanah, yaitu, kedalamanan muka airtanah sebesar 35\%, ketebalan akuifer sebesar $35 \%$, dan DHL sebesar 30\%. Hasil penelitian menunjukkan bahwa dari seluruh luasan wilayah kajian yang diteliti, mayoritas potensi airtanah tergolong pada kelas baik $(49,8 \%)$ dan sedang $(48,7 \%)$. Sementara itu, kelas miskin airtanah hanya menempati luasan yang sangat kecil, yaitu hanya 1,5\% dari total luas wilayah kajian. Sementara itu, jika ditinjau tiap satuan bentuk lahan, maka bentuklahan Beting Gisik mempunyai sebaran potensi airtanah yang paling luas (30,4\%), yang disusul oleh bentuklahan Dataran Aluvial (11\%).

Kata kunci: Potensi Airtanah, SIG, bentuklahan, parameter lapangan airtanah 


\section{BAB I. PENDAHULUAN}

\subsection{Latar Belakang dan Permasalahan}

Kelangkaan airtanah, baik dari segi kualitas maupun kuantitas, untuk memenuhi kebutuhan air penduduk merupakan isu strategis yang mencuat akhir-akhir ini (Adji dan Noordianto, 2006). Bebagai permasalahan yang sering timbul akibat adanya kesalahan manajemen airtanah diantaranya adalah penurunan muka airtanah (cone of depression), degradasi kualitas airtanah, intrusi air laut, dan fenomena penurunan muka tanah (land subsidence) (Adji, 2003; Adji, 2007).

Airtanah bersifat dinamis dan dipengaruhi oleh sejumlah faktor alam. Geologi dan geomorfologi sangat menentukan prospek tanah di suatu daerah (Sejati dan Adji, 2013). Struktur geologi mempengaruhi arah gerakan airtanah, jenis dan ketebalan akuifer. Stratigrafi dari beberapa lapisan batuan dapat berpengaruh pada jenis, kedalaman, dan ketebalan akuifer. Sementara itu, pengaruh litologi akuifer adalah pada permeabilitas dan konsentrasi ion terlarut. Morfologi relief permukaan bumi mempengaruhi terjadinya dan arah gerakan airtanah. Perubahan topografi permukaan mempengaruhi kedalaman muka airtanah dan arah gerakan airtanah. Morfogenesis mempengaruhi permeabilitas, porositas, dan laju infiltrasi. Karena ada hubungan yang kuat antara kondisi geologi-geomorfologi dan airtanah, maka kondisi geologi dan geomorfologi dapat dipelajari untuk menentukan distribusi sumber daya potensial airtanah di suatu daerah (Santosa dan Adji, 2014).

Dengan perkembangan teknologi penginderaan jauh dan kinerja spasialnya yang akurat dalam proses georeferensi, maka faktor-faktor yang berpengaruh pada prospek airtanah dapat lebih mudah diidentifikasi dalam skala yang luas. Daerah kepesisiran merupakan daerah yang mempunyai keragaman bentuk lahan yang cukup kompleks karena banyaknya proses geomorfologi yang bekerja baik di masa lampau maupun masa sekarang. Di antara proses-proses tersebut adalah proses marine, angin, maupun aluvial. Karena kompleksnya bentuk lahan hasil proses tersebut, secara teoritis akan mengontrol kondisi airtanahnya. Maka penelitian ini akan mengaplikasikan SIG untuk memetakan potensi airtanah pada suatu daerah yang mempunyai keragaman bentuk lahan, yakni di daerah kepesisiran.

Pada kebanyakan studi zonasi potensi airtanah yang sudah banyak dilakukan, dalam hal ini umumnya ahli SIG menggunakan faktor-faktor penentu potensi airtanah seperti faktor geologi, kelerengan, vegetasi, penggunaan lahan dan iklim untuk membuat zonasi 
potensi airtanah. Adapun dalam studi ini, potensi airtanah diperkirakan dengan memetakan beberapa parameter berpengaruh yang mudah diukur di lapangan (Adji and Sejati, 2014). Beberapa parameter spesifik potensi airtanah yang berhubungan dengan kondisi geologi dan geomorfologi, yaitu sebagai berikut: (1) kedalaman ke muka airtanah, yang berhubungan dengan kondisi topografi, (2) fluktuasi muka airtanah, yang erat berhubungan dengan topografi dan litologi, (3) Daya Hantar Listrik, sebagai salah satu parameter kualitas air, yang berhubungan dengan penggunaan lahan dan jenis litologi, dan (4) ketebalan akuifer, yang sangat erat kaitannya dengan struktur geologi dan paleo geomorfologi. Selanjutnya, dengan menggunakan parameter-parameter ini, maka SIG mempunyai fasilitas untuk membuat zona potensi airtanah. Keuntungan lain dari metode ini bahwasanya tidak perlu dilakukan pengecekan lapangan setelah zonasi didapatkan, karena zonasi yang ada sudah merupakan hasil dari proses SIG yang databasenya merupakan hasil pengukuran lapangan.

\subsection{TUJUAN DAN MANFAAT PENELITIAN}

Tujuan dari penelitian ini adalah untuk menyajikan peta distribusi potensi airtanah yang tergantung pada empat faktor airtanah potensial yang dapat disurvei di lapangan dan untuk menggabungkan kondisi geomorfologi di daerah penelitian, yang dibantu dengan fasilitas geoprocessing pada SIG.

Sementara itu, manfaat yang diharapkan yakni baik secara metodologi maupun untuk memperoleh zonasi potensi airtanah untuk keperluan pemanfaatan dan konservasi airtanah di wilayah kepesisiran.

\subsection{LANDASAN TEORI}

\section{$\underline{\text { Airtanah }}$}

Airtanah adalah air yang berada di bawah permukaan tanah pada zona jenuh air, dengan tekanan hidrostatis sama atau lebih besar daripada tekanan udara. Sumber utama airtanah adalah air hujan yang meresap ke dalam tanah mengikuti suatu proses yang disebut sebagai daur hidrologi (Purnama, 2000). Menurut Todd (1980), airtanah adalah air yang terdapat dalam tanah atau batuan, menempati ruang-ruang antar butir batuan serta berada dalam celah-celah batuan. Berdasarkan daur hidrologi, airtanah berasal dari air hujan yang bergerak ke bawah melalui zona aerasi yaitu zona yang berupa pori-pori tanah berisi air dan udara dalam jumlah yang berbeda-beda. 
Air yang melalui zona aerasi ditahan oleh gaya-gaya kapiler pada pori-pori yang kecil atau oleh tarikan molekuler di sekitar partikel-partikel tanah. Apabila kapasitas retensi dari tanah pada zona ini telah dihabiskan, air akan bergerak ke bawah menuju poripori tanah atau batuan yang jenuh air yang disebut sebagai zona jenuh air (zone of saturation). Air yang terdapat pada zona jenuh air inilah yang disebut sebagai airtanah (Linsley, 1985). Perbedaan kondisi fisik secara alami akan mengakibatkan air dalam zonasi ini akan bergerak/mengalir baik secara gravitasi, perbedaan tekanan, kontrol struktur batuan dan parameter lainnya. Kondisi inilah yang disebut sebagai aliran airtanah.Daerah aliran airtanah ini selanjutnya disebut sebagai daerah aliran (flow zone).

Airtanah ditemukan pada formasi geologi permeabel (tembus air) yang disebut sebagai akuifer.Akuifer merupakan formasi pengikat air yang memungkinkan jumlah air yang cukup besar untuk bergerak melaluinya pada kondisi lapangan yang biasa.Pada akuifer, airtanah menempati pori-pori batuan, retakan ataupun patahan pada suatu batuan. Secara umum airtanah akan mengalir sangat perlahan melalui suatu celah yang sangat kecil dan atau melalui butiran antar batuan. formasi geologi merupakan faktor yang mempengaruhi proses terbentuknya airtanah. Formasi geologi adalah formasi batuan atau material lain yang berfungsi menyimpan airtanah dalam jumlah besar (Asdak, 1995). Dalam proses pembentukan airtanah, formasi-formasi yang berisi dan memancarkan airtanah dikenal sebagai akuifer (Linsley, 1985).

Airtanah tidak dapat ditemukan di setiap tempat.Ada tidaknya airtanah tergantung dari ada tidaknya lapisan batuan yang dapat mengandung airtanah yang disebut dengan akuifer.Menurut PP No. 43 tahun 2008 akuifer merupakan lapisan batuan jenuh airtanah yang dapat menyimpan dan meloloskan air dalam jumlah yang cukup.Artinya dapat mensuplai suatu sumur atau mata air pada suatu periode tertentu.

Akuifer (Gambar 1.1) sering pula disebut waduk air atau formasi air. Menurut Krussman dan Ridder (1970) bahwa akuifer dapat dikelompokkan menjadi barbagai macam, yaitu :

a. Akuifer bebas (unconfined aquifer) yaitu lapisan air yang hanya sebagian terisi oleh air dan berada di atas lapisan kedap air. Permukaan tanah pada akuifer ini disebut dengan water table (preatik level), yaitu permukaan air yang mempunyai tekanan hidrostatik sama dengan atmosfer. Airtanah yang berasal dari akuifer bebas pada umumnya ditemukan pada kedalaman yang relatif dangkal atau kurang dari 40 m. Kasus khusus dari akuifer bebasa adalah akuifer menggantung (perched aquifer) yang terjadi akibat 
terpisahnya airtanah dari tubuh airtanah utama oleh suatu formasi batuan kedap air (Kodoatie, 1996)

b. Akuifer tertekan (confined aquifer) yaitu akuifer yang seluruh jumlahnya dibatasi oleh lapisan kedap air, baik yang atas maupun yang berada di bawah, serta mempunyai tekanan lebih besar daripada tekanan atmosfer.

c. Akuifer semi tertekan (semi confined aquifer) yaitu akuifer yang seluruhnya jenih air, dimana bagian atasnya dibatasi dengan lapisan semi lolos air pada bagian bawahnya merupakan lapisan kedap air.

d. Akuifer semi bebas (semi uncinfined aquifer) yaitu akuifer yang bagian bawahnya merupakan lapisan kedap air, sednagkan material atasnya merupakan material berbutir halus sehingga pada lapisan penutupnya masih memungkinkan adanya gerakan air. Dengan demikian akifer ini merupakan peralihan antara akuifer bebas dengan akuifer semi tertekan.

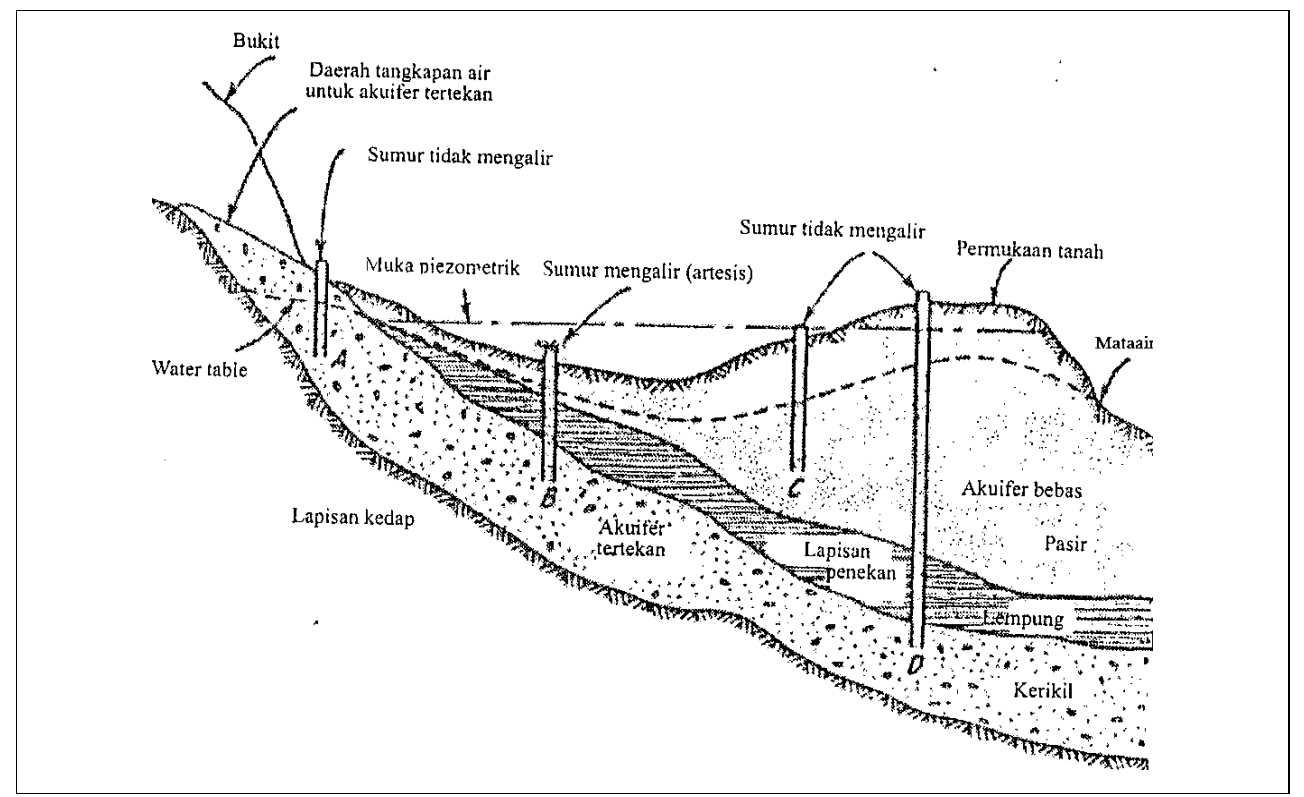

Gambar 1.1.Akuifer Bebas dan Tertekan (Israelsen dan Hanses, 1962 dalam Purnama 2010)

\section{Geolistrik}

Geolistrik merupakan metode pendugaan area keterdapatan airtanah dan kedalamannya dengan prinsip perbedaan nilai tahanan jenis tiap batuan (Lowrie, 2007).Salah satu metode geolistrik yang dapat dilakukan adalah dengan menggunakan metode ERT (Electrical Resistivity Tomography).ERT merupakan metode yang digunakan untuk menduga jenis dan susunan material permukaan bumi berdasarkan distribusi spasial 
nilai resistivitasnya (Lowrie, 2007) ERT disebut juga dengan Sub Surface Imaging (Telford et al, 2004) atau Resitivity Profiling (Milsom, 2003).

Menurut Sheriff (2002) tomography merupakansebuah metode untuk mencari sifat distribusi, kecepatan dan pantulan dari serangkaian observasi berulang-ulang yang menggunakan suatu penerima dan sumber, sedangkan berdasarkan Encyclopedic Dictionary of Applied Geophysics, tomografi merupakan penentuan distribusi resistivitas menggunakan pemancar dari satu tempat ke tempat lainnya. ERT merupakan teknik untuk pencitraan struktur bawah permukaan menggunakan arus konduksi listrik (Daily dan Ramirez, 2000).ERT diusulkan 22 tahun yang lalu independen oleh Henderson dan Webster (1978) sebagai modalitas pencitraan medis dan oleh Lytle dan Dines (1978) sebagai alat pencitraan geofisika. Metode ERT berbeda dengan metode VES (Vertical Electrical Sounding).

Dalam geolistrik, terdapat berbagai macam konfigurasi susunan elektroda yang sering disebut dengan geometric factor. Konfigurasi susunan elektroda tersebut adalah Wenner alpha, Wenner Beta, Dipole-Dipole, dan Wenner Schlumberger.Salh satu konfigurasi susunan elektroda yang sering digunakan adalah konfigurasi Wenner Schlumberger karena dianggap paling baik tingkat keakuratannya.

\section{Sistem Informasi Geografis untuk Penyelidikan Airtanah}

Ulasan yang sangat baik terkait dengan teknik penginderaan jauh dalam penyelidikan airtanah dilakukan oleh Engman dan Gurney (1991), Bobba, et al. (1992), Meijerink (2000), dan Rai, et al. (2005) . Dalam beberapa tahun terakhir, seiring membaiknya Sistem Informasi Geografis (SIG) menjadi lebih modern dengan berbagai fasilitasnya, maka pemetaan zonasi potensi airtanah menjadi lebih mudah dan lebih cepat. Beberapa studi kasus dengan mengintegrasikan penginderaan jauh dan teknologi SIG untuk menentukan zonasi potensi airtanah telah dilakukan oleh Shahid dan Nath (2002), Rose dan Krishnan (2009), Nagarajan dan Singh (2009), Yeh, et al. (2009), dan Preeja, et al. (2010). Studi-studi ini menggambarkan zonasi potensial airtanah di suatu wilayah dikontrol oleh faktor-faktor yang berpengaruh terhadap prospek airtanah, seperti kondisi tanah, kemiringan lereng, penggunaan lahan, litologi, dan topografi, dll.

Metode overlay indeks tertimbang (weighted indeks overlay method) diaplikasikan untuk menentukan zonasi potensi tanah. Metode ini sangat sederhana dan memfasilitasi analisis dari kombinasi peta multi-kelas. Efektivitas metode ini tergantung pada penilaian si pelaku yang dapat dimasukkan dalam analisis. Metode ini mempertimbangkan 
pentingnya bobot dan kelas parameter-parameter yang digunakan, sehingga tidak ada skala standar. Untuk melakukan hal ini, kriteria untuk analisis harus didefinisikan, dan setiap parameter harus diberi bobot tertentu, ergantung dari sekuat apa parameter ini mempengaruhi potensi airtanah (Saraf dan Choudhury, 1998). Atau dengan kata lain, menurut Preeja, et al. (2010), bobot dari masing-masing individu parameter dan nilai parameter diprioritaskan secara berbeda berdasarkan pengaruh mereka pada kondisi airtanah. 


\section{BAB II. CARA PENELITIAN}

\subsection{Alat dan bahan}

Alat utama dan bahan yang digunakan dalam penelitian ini adalah alat lapangan dan alat perangkat sistem komputer untuk modelling dan identifikasi bentuklahan.

$\underline{\text { Perangkat untuk modelling dan identifikasi bentuklahan meliputi : }}$

1. Perangkat Keras (CPU, komputer, printer, monitor)

2. Stereoskop Cermin

3. Alat untuk survey lapangan meliputi :

4. Kompas dan palu geologi untuk identifikasi mineral akuifer

5. GPS, untuk mengetahui posisi di lapangan

6. Perangkat survey geolistrik, untuk mendapatkan data tahanan jenis perlapisan batuan.

7. $\mathrm{pH}$ meter, EC meter, dll, untuk identifikasi awal kualitas air

8. Kamera

9. Meteran

Bahan utama yang digunakan adalah:

1. Peta topografi dan Rupabumi skala 1:25.000 dan 1:50.000

2. Foto udara pankromatik skala 1:30.000

3. Citra digital Landsat ETM+

4. Peta Geologi Skala 1:100.000

\subsection{Tahapan Penelitian}

Penelitian ini akan meliputi tahapan persiapan, kerja laboratorium, kerja lapangan, dan tahap penyelesaian.

\section{Tahap persiapan meliputi :}

1. Pengumpulan data sekunder

2. Pengumpulan peta topografi, citra landsat ETM dan foto udara pankromatik

3. Pengurusan ijin penelitian

\section{Tahap keria laboratorium meliputi :}

1. Identifikasi sebaran bentuklahan dari citra, foto udara, dan peta

2. Penentuan distribusi akuifer sementara

3. Penentuan lokasi sampling dan pengukuran

\section{Tahap kerja lapangan meliputi :}

1. Cek lapangan hasil interpretasi bentuklahan 
2. Pengukuran tinggi muka air sumur dan pengukuran DHL

3. Pengambilan data geolistrik,

\section{Tahap Penyelesaian meliputi :}

1. Penyusunan model akhir resistivitas dua dimensi akuifer penyimpan airtanah

2. Melakukan zonasi potensi airtanah

3. Penulisan laporan

4. Presentasi hasil dan perbaikan

\subsection{Analisis}

$\underline{\text { Analisis penentuan tebal akuifer }}$

Analisis data resistivitas perlapisan batuan dilakukan dengan bantuan software IP2Win versi 3.0.1a. (Moscow State University, 2001). Data pada masing-masing titik diinterpretasi dengan membuat kurva hasil persinggungan garis-garis asymtot yang mewakili variasi vertikal resistivity batuan, seperti yang disajikan pada Gambar 2.1. Selanjutnya, IP2 Win juga dapat secara langsung mengkelaskan nilai resistivitas atas dasar materi yang dilalui oleh listrik yang dihantarkan batuan dan diinterpretasikan oleh alat geolistrik (Santosa dan Adji, 2006)

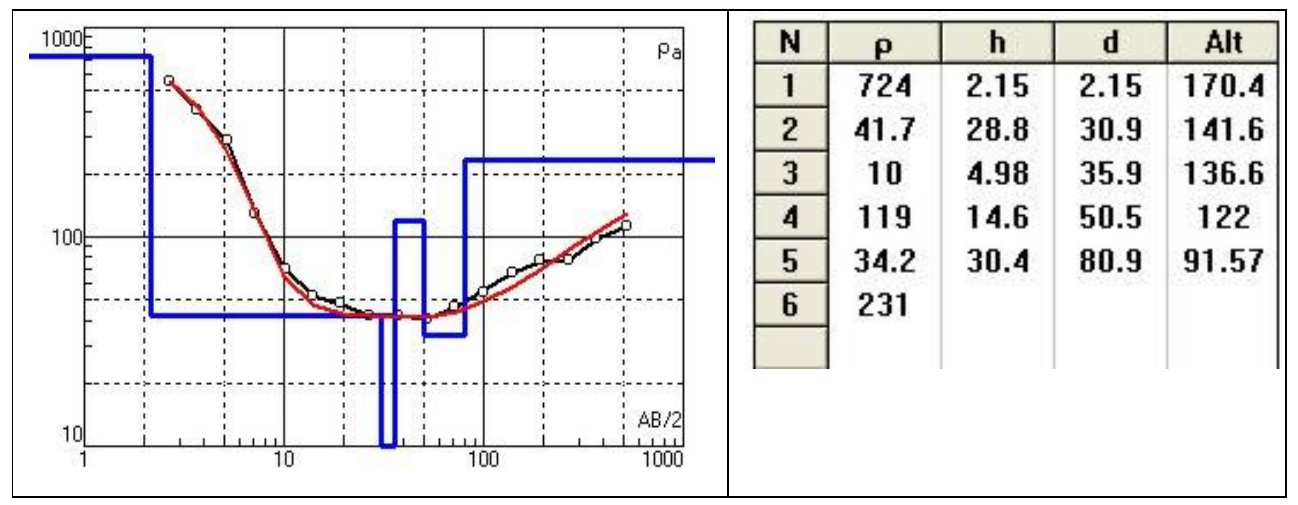

Gambar 2.1. Interpretasi perlapisan batuan vertikal oleh IP2Win

Selanjutnya, untuk menganalisis sebaran resistivitas secara keruangan, perlu ditentukan cross section nilai resistivitas dengan cara membuat lintasan 2 dimensi seperti yang disajikan pada Gambar 2.2. 


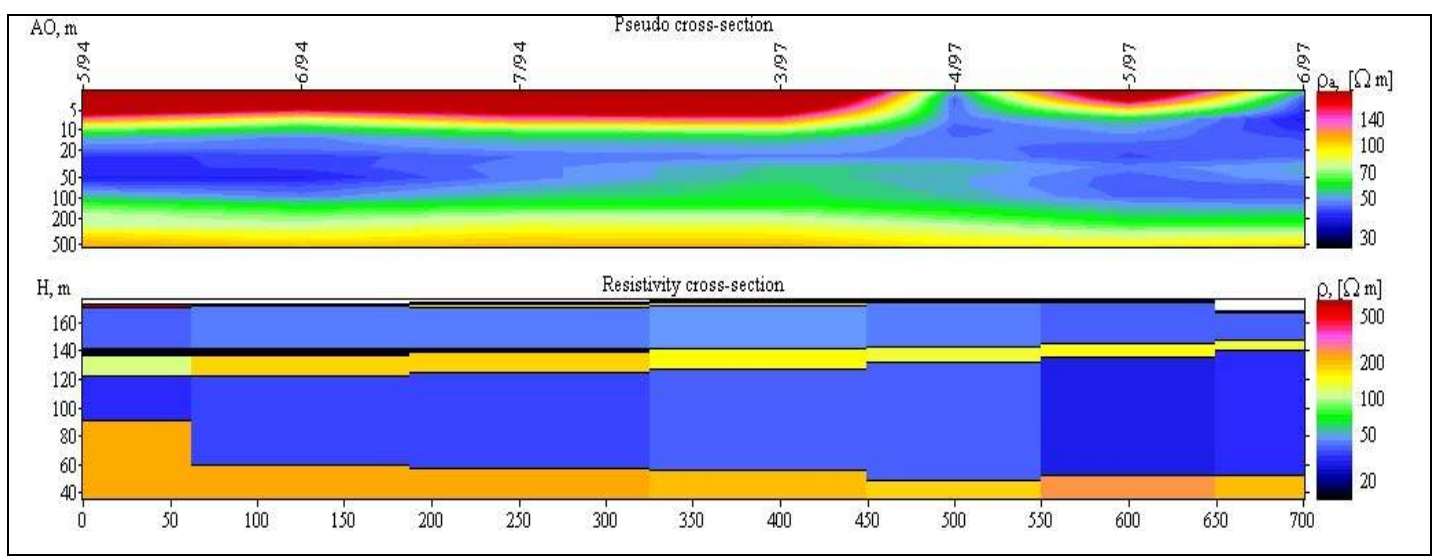

Gambar 2.2. Lintasan 2 dimensi nilai resistivitas batuan

Setelah diperoleh lintasan-lintasan dari beberapa titik pengukuran, maka untuk mengetahui lapisan penyimpan airtanah, haruslah dibuat kriteria nilai resistivitas berapa yang mampu menyimpan airtanah seperti disajikan pada Tabel 2.1.

Tabel 2.1. Nilai Tahanan Jenis Hubungannya Dengan Kondisi Airtanah

\begin{tabular}{|c|c|c|c|c|}
\hline No & $\begin{array}{c}\text { Tahanan jenis } \\
(\Omega \mathrm{m})\end{array}$ & Kondisi Airtanah & Material & Bentuklahan \\
\hline 1 & $600-2000$ & kering & pasir pantai & marine \\
\hline 2 & $150-600$ & jenuh airtanah & pasir pantai & marine \\
\hline 3 & $10-150$ & jenuh airtanah & aluvium & dataran aluvial \\
\hline 4 & $2-10$ & payau & $\begin{array}{c}\text { pasir sangat halus }+ \\
\text { lempung }\end{array}$ & fluvio marine \\
\hline 5 & $5-10$ & tawar - payau & gamping napalan & lereng perbukitan \\
\hline 6 & $10-25$ & tawar & bereksi andesit tua & perbukitan \\
\hline
\end{tabular}

Sumber : Loke (1999), Zohdy (1989), Acworth (2001) dengan modifikasi

\section{$\underline{\text { Analisis Zonasi Potensi Airtanah }}$}

Potensi airtanah bebas merupakan gambaran mengenai kondisi airtanah yang berpotensi untuk dapat dimanfaatkan untuk memenuhi kebutuhan sehari-hari, baik kebutuhan domestik, industri, kebutuhan pertanian, dan sebagainya. Potensi airtanah ini dapat dikaji dari segi kualitas maupun kuantitasnya. Seberapa besar potensi airtanah dipengaruhi oleh beberapa faktor, diantaranya kondisi akuifer yang meliputi keberadaan, persebaran, dan tebal akuifer yang berpotensi untuk diturap airtanahnya yang mana data tersebut diperoleh berdasarkan pendugaan geolistrik; kemudian kedalaman muka airtanah yang diketahui dari hasil survei pada sumur gali penduduk, fluktuasi airtanah bebas yang diperoleh dari hasil pengamatan lapangan dengan didukung data hasil wawancara dengan penduduk setempat, kualitas airtanah yang dilakukan dengan pendekatan nilai DHL atau Daya Hantar Listrik, dan tingkat penurapannya. Oleh karena itu, zonasi potensi airtanah bebas pada daerah penelitian dilakukan dengan pertimbangan faktor-faktor tersebut. 
Secara tidak langsung, penggunaan Sistem Informasi Geografis (SIG) dan Remote Sensing (RS) dapat digunakan untuk membuat Peta Zonasi Potensi Airtanah pada suatu wilayah dengan menggunakan beberapa pendekatan faktor-faktor penentu potensi airtanah, dan didaerah penelitian adalah seperti yang disajian pada Tabel 2.2.

Tabel 2.2. Parameter Penyusun Potensi Airtanah di Daerah Penelitian

\begin{tabular}{|c|c|c|c|c|c|}
\hline No & Parameter lapangan & $\begin{array}{c}\text { Bobot } \\
(\%)\end{array}$ & Kelas & Category & Skor \\
\hline \multirow{3}{*}{1.} & \multirow{3}{*}{ Kedalaman Muka Airtanah (m) } & \multirow{3}{*}{30} & $0-2$ & dangkal & 10 \\
\hline & & & $2-6$ & sedang & 8 \\
\hline & & & $>6$ & dalam & 5 \\
\hline \multirow{3}{*}{2.} & \multirow{3}{*}{ Tebal Akuifer (m) } & \multirow{3}{*}{30} & $0-30$ & tebal & 3 \\
\hline & & & $30-60$ & sedang & 8 \\
\hline & & & $>60$ & tinggi & 10 \\
\hline \multirow{3}{*}{3.} & \multirow{3}{*}{ Daya Hantar Listrik $(\mu \mathrm{S} / \mathrm{cm})$} & \multirow{3}{*}{20} & $0-250$ & tawar & 10 \\
\hline & & & $250-500$ & sedang & 6 \\
\hline & & & $>500$ & tercemar & 2 \\
\hline
\end{tabular}

Faktor-faktor penentu tersebut antara lain adalah kondisi iklim, topografi, geologi, geomorfologi, vegetasi, dan penggunaan lahan. Metode yang biasa digunakan atau dipakai dikenal dengan nama Weighted Index Overlay Model for Groundwater Prospects atau model yang dibuat dengan melakukan overlay atau tumpang susun peta pada faktor-faktor berpengaruh yang diberi bobot tertentu. Dalam penelitian ini pembuatan Peta Zonasi Potensi Airtanah (Gambar 3) dibuat dengan menggunakan pendekatan faktor pembobot berupa Peta Kedalaman Muka Airtanah (TMA), Peta Daya Hantar Listrik, Peta Fluktuasi Muka Airtanah dan Peta Ketebalan Akuifer Berpotensi Tinggi di daerah penelitian. Pendekatan faktor pembobot yang digunakan sebagai parameter penyusun Peta Zonasi Potensi Airtanah di daerah penelitian disajikan dalam Tabel 2.2. Berdasarkan pendekatan faktor pembobot tersebut diperoleh integrasi faktor pembobot dengan potensi airtanah rendah hingga tinggi dan disajikan padaTabel 2.3.

Tabel 2.3. Intregrasi Faktor Permbobot Potensi Airtanah di Daerah Penelitian

\begin{tabular}{|l|l|c|}
\hline No & \multicolumn{1}{|c|}{ Potensi Airtanah } & Nilai Pembobot \\
\hline 1 & Potensi Airtanah Rendah & $<6$ \\
\hline 2 & Potensi Airtanah Sedang & $6-8$ \\
\hline 3 & Potensi Airtanah Tinggi & $>8$ \\
\hline
\end{tabular}




\section{BAB III. HASIL PENELITIAN DAN PEMBAHASAN}

\subsection{Kondisi singkat daerah penelitian}

Daerah penelitian merupakan bagian dari Kabupaten Bantul, yang terletak antara Sungai Opak di sebelah utara dan barat dan Samudera Hindia di sebelah selatan. Secara astronomis, daerah penelitian terletak antara 9117011-9112518 mU dan 420472 - 427274 $\mathrm{mT}$. Elevasi bervariasi dari $0.5 \mathrm{~m}$ di atas permukaan laut (dpl) di selatan untuk sekitar 10 dpl utara. Curah hujan tahunan rata-rata adalah $1.811 \mathrm{~mm}$, dan peningkatan curah hujan terjadi dari Januari-Februari. Suhu rata-rata tahunan adalah antara $26-27^{\circ} \mathrm{C}$.

Menurut Bemmelen (1970), litologi utama di daerah ini di daerah penelitian terdiri dari: (1)Aluvium (Qa) yang berisi kerakal, pasir, lanau dan lempung sepanjang Sungai Opak dan dataran pantai. Material aluvium ini berdampingan dengan aluvium rombakan bahan volkanik yang dalam peta dinyatakan dalam Qmi; (2) Endapan Gunungapi Merapi Muda (Qmi) yang berisi tuf, abu, breksi, aglomerat dan leleran lava tak terpisahkan. Hasil pelapukan membentuk lereng bagian bawah dan dataran yang meluas di sebelah selatan, terutama terdiri dari endapan aluvium rombakan volkanik; dan (3) Formasi Ngelanggeran (Tmn), yang terdiri dari breksi volkanik, breksi aliran, aglomerat, lava dan tuf. Jenis batuan ini hanya dijumpai sedikit di daerah penelitianan. Berdasarkan bentang alam di daerah penelitian, terdapat 4 bentuklahan yaitu: Beting Gisik (Beach Ridges), Pantai (Beach), Gumuk Pasir (Sand Dunes), Dataran Aluvial (Alluvial Plain), dan Dataran Banjir (Flood Plain) seperti yang disajikan pada Gambar 3.1. Ada pun bentuklahan Horst dan Foot Slope tidak dikaji pada penelitian ini.

\subsection{Kedalaman muka airtanah}

Pengukuran parameter kedalaman muka airtanah dilakukan pada 90 sumur gali (Tabel 3.1.) dari Tabel 3.1. tersebut, tampak bahwak kedalaman muka airtanah di daerah penelitian bervariasi antara 0,2 - 9,5 meter. Variasi tersebut kemudian diklasifikasikan menjadi tiga kelas, yaitu: (1) dangkal (0 - 2 meter), (2) sedang (2- $4 \mathrm{~m}$ ), dan (3) dalam (> 4 meter). Distribusi spasial kedalaman muka airtanah di daerah penelitian disajikan pada Gambar 3.2. 


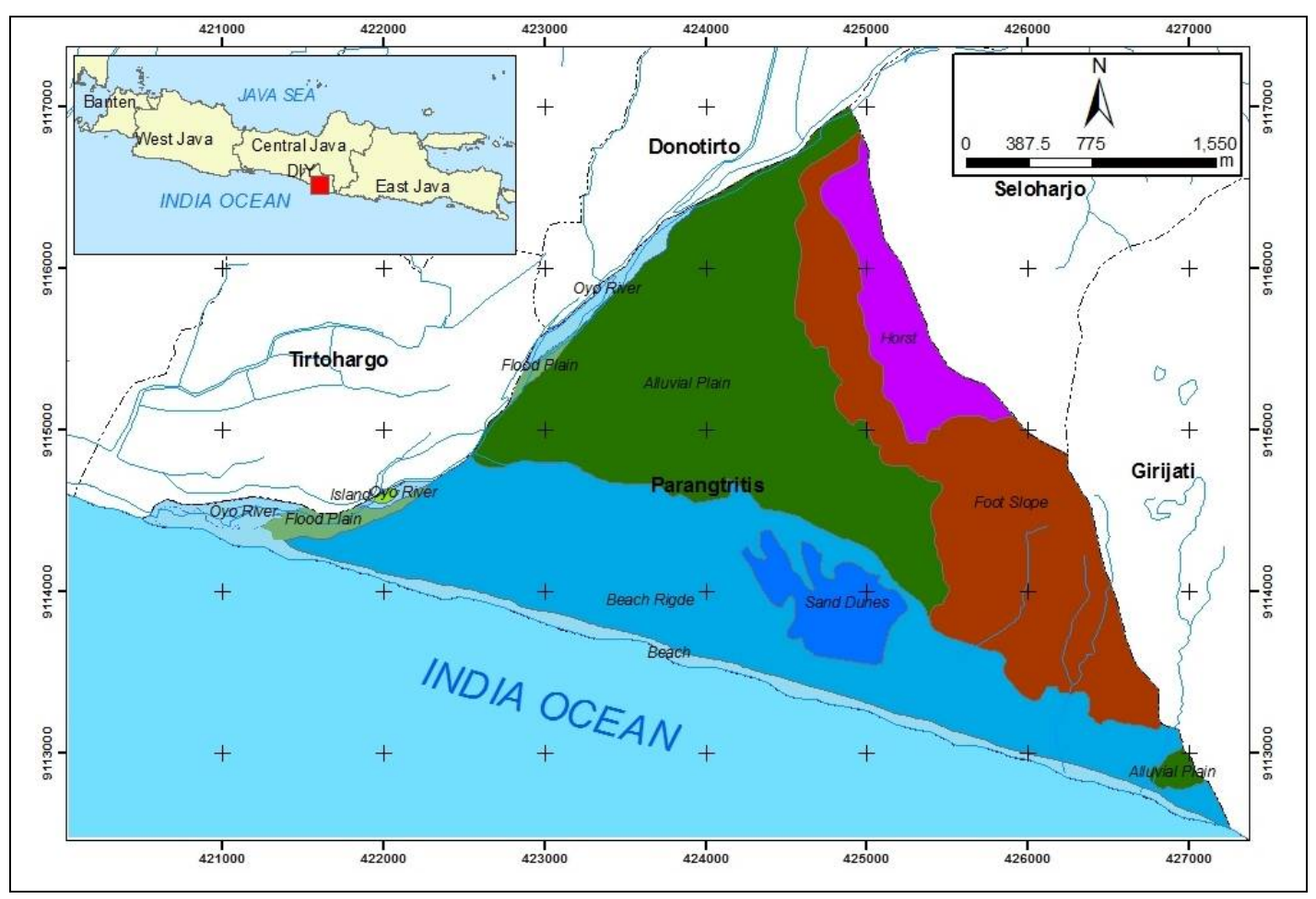

Gambar 3.1. Bentuklahan di daerah penelitian

Tabel 3.1. Data Kedalaman Muka Airtanah dan DHL di Daerah Penelitian

\begin{tabular}{|c|c|c|c|c|c|}
\hline No & $\begin{array}{c}\text { Koordinat } \\
\mathrm{X} \\
\end{array}$ & $\begin{array}{c}\text { Koordinat } \\
\text { Y }\end{array}$ & $\begin{array}{c}\text { Elevasi ( } \mathrm{m} \\
\text { dpal) }\end{array}$ & $\begin{array}{c}\text { TMA } \\
(\mathrm{m})\end{array}$ & $\begin{array}{c}\text { DHL (mikro } \\
\text { mhos/cm) }\end{array}$ \\
\hline 1 & 426795 & 9113060 & 6,29 & 3,71 & 394 \\
\hline 2 & 426759 & 9112940 & 7,38 & 7,20 & 444 \\
\hline 3 & 426748 & 9112799 & 4,42 & 3,20 & 615 \\
\hline 4 & 426560 & 9113125 & 10,05 & 8,81 & 529 \\
\hline 5 & 426472 & 9112972 & 8,48 & 5,98 & 448 \\
\hline 6 & 426326 & 9112993 & 6,25 & 2,67 & 544 \\
\hline 7 & 426383 & 9113158 & 6,25 & 1,73 & 470 \\
\hline 8 & 426089 & 9113308 & 7,37 & 5,24 & 4790 \\
\hline 9 & 425966 & 9113067 & 9 & 1,88 & 365 \\
\hline 10 & 425631 & 9113166 & 2,74 & 0,95 & 433 \\
\hline 11 & 425544 & 9113223 & 3,38 & 1,13 & 351 \\
\hline 12 & 425818 & 9113500 & 12,21 & 7,44 & 440 \\
\hline 13 & 425007 & 9114221 & 10,07 & 6,81 & 410 \\
\hline 14 & 424899 & 9114300 & 7,57 & 5,10 & 846 \\
\hline 15 & 424704 & 9114342 & 9,44 & 7,22 & 372 \\
\hline 16 & 423594 & 9114494 & 6,6 & 0,33 & 275 \\
\hline 17 & 423297 & 9114460 & 6,25 & 2,93 & 378 \\
\hline 18 & 423383 & 9114659 & 6,25 & 0,25 & 520 \\
\hline 19 & 422903 & 9114606 & 6,25 & 0,03 & 1570 \\
\hline 20 & 422545 & 9114569 & 6,25 & 1,97 & 281 \\
\hline
\end{tabular}




\begin{tabular}{|c|c|c|c|c|c|}
\hline 21 & 425890 & 9113637 & 12,5 & 9,78 & 593 \\
\hline 22 & 425715 & 9113650 & 10,73 & 7,30 & 520 \\
\hline 23 & 425736 & 9113468 & 6,25 & 3,15 & 457 \\
\hline 24 & 425399 & 9113341 & 4,55 & 3,27 & 367 \\
\hline 25 & 425347 & 9113493 & 6,25 & 3,45 & 440 \\
\hline 26 & 425343 & 9113517 & 6,25 & 2,9 & 356 \\
\hline 27 & 425129 & 9113554 & 6,25 & 4,25 & 298 \\
\hline 28 & 424700 & 9113626 & 6,25 & 3,53 & 165 \\
\hline 29 & 424468 & 9113655 & 6,25 & 4,25 & 288 \\
\hline 30 & 423789 & 9113710 & 4,26 & 1,09 & 445 \\
\hline 31 & 423746 & 9113760 & 4,76 & 0,14 & 422 \\
\hline 32 & 422932 & 9113965 & 3,93 & 0,28 & 225 \\
\hline 33 & 422788 & 9114108 & 5,73 & 2,38 & 517 \\
\hline 34 & 422386 & 9114098 & 2,39 & 1,33 & 254 \\
\hline 35 & 421942 & 9114221 & 2,99 & 0,81 & 834 \\
\hline 36 & 421868 & 9114215 & 2,67 & 1,58 & 250 \\
\hline 37 & 422008 & 9114147 & 2,24 & 1,76 & 818 \\
\hline 38 & 422153 & 9114231 & 3,26 & 0,84 & 284 \\
\hline 39 & 422445 & 9114631 & 6,25 & 1,80 & 518 \\
\hline 40 & 422520 & 9114804 & 6,31 & 0,81 & 382 \\
\hline 41 & 422742 & 9114972 & 6,25 & 2,05 & 453 \\
\hline 42 & 422905 & 9115057 & 6,25 & 1,15 & 517 \\
\hline 43 & 423478 & 9114840 & 6,25 & 2,95 & 521 \\
\hline 44 & 423478 & 9114840 & 6,25 & 2,95 & 459 \\
\hline 45 & 423056 & 9115075 & 6,25 & 2,65 & 560 \\
\hline 46 & 423090 & 9115424 & 6,25 & 1,43 & 722 \\
\hline 47 & 423177 & 9115503 & 6,25 & 1,65 & 738 \\
\hline 48 & 423412 & 9115658 & 6,25 & 1,85 & 576 \\
\hline 49 & 423671 & 9115900 & 6,25 & 1,77 & 552 \\
\hline 50 & 423861 & 9116149 & 6,25 & 1,71 & 535 \\
\hline 51 & 425530 & 9113733 & 16,8 & 11,26 & 358 \\
\hline 52 & 425260 & 9113958 & 12,5 & 7,05 & 251 \\
\hline 53 & 425052 & 9114310 & 7,18 & 4,38 & 719 \\
\hline 54 & 425022 & 9114283 & 6,46 & 4,30 & 628 \\
\hline 55 & 425000 & 9114282 & 6,64 & 4,14 & 516 \\
\hline 56 & 425160 & 9114478 & 9,38 & 7,58 & 450 \\
\hline 57 & 424875 & 9114444 & 6,25 & 4,15 & 570 \\
\hline 58 & 424898 & 9114486 & 6,25 & 4,05 & 570 \\
\hline 59 & 424773 & 9114823 & 6,25 & 5,05 & 404 \\
\hline 60 & 424883 & 9114937 & 9,35 & 6,35 & 508 \\
\hline 61 & 424663 & 9115208 & 7,96 & 2,80 & 523 \\
\hline 62 & 424847 & 9115004 & 10,28 & 7,48 & 556 \\
\hline 63 & 424552 & 9115755 & 11,7 & 3,25 & 638 \\
\hline
\end{tabular}




\begin{tabular}{|c|c|c|c|c|c|}
\hline 64 & 424782 & 9114341 & 7,59 & 4,97 & 397 \\
\hline 65 & 424646 & 9114408 & 7,45 & 3,99 & 208 \\
\hline 66 & 424554 & 9114498 & 6,25 & 5,30 & 395 \\
\hline 67 & 424463 & 9114512 & 6,25 & 5,33 & 368 \\
\hline 68 & 423364 & 9115155 & 6,25 & 1,41 & 730 \\
\hline 69 & 423441 & 9115164 & 6,25 & 3,15 & 791 \\
\hline 70 & 424232 & 9115323 & 6,25 & 4,09 & 660 \\
\hline 71 & 423877 & 9115603 & 6,25 & 1,55 & 912 \\
\hline 72 & 424073 & 9115677 & 6,25 & 0,75 & 800 \\
\hline 73 & 424180 & 9115940 & 6,25 & 0,35 & 598 \\
\hline 74 & 424197 & 9116108 & 6,25 & 0,65 & 531 \\
\hline 75 & 423906 & 9116211 & 6,25 & 0,25 & 556 \\
\hline 76 & 424282 & 9116465 & 6,53 & 0,57 & 605 \\
\hline 77 & 424577 & 9116554 & 8,98 & 3,46 & 652 \\
\hline 78 & 422131 & 9114100 & 3,78 & 0,22 & 1178 \\
\hline 79 & 422147 & 9114142 & 4,21 & 0,25 & 842 \\
\hline 80 & 421946 & 9114156 & 3,98 & 0,68 & 2723 \\
\hline 81 & 424400 & 9113664 & 6,15 & 3,17 & 476 \\
\hline 82 & 425179 & 9113642 & 5,25 & 1,84 & 405 \\
\hline 83 & 425259 & 9113764 & 4,82 & 2,11 & 357 \\
\hline 84 & 425469 & 9113268 & 3,82 & 0,22 & 798 \\
\hline 85 & 426633 & 9112846 & 4,25 & 2,25 & 1390 \\
\hline 86 & 425060 & 9114234 & 6,98 & 1,86 & 602 \\
\hline 87 & 424956 & 9114288 & 7,61 & 3,09 & 549 \\
\hline 88 & 422906 & 9114644 & 7,87 & 0,54 & 717 \\
\hline 89 & 422897 & 9114744 & 7,98 & 0,78 & 547 \\
\hline 90 & 422827 & 9114632 & 7,34 & 0,34 & 290 \\
\hline
\end{tabular}

Sumber: Pengukuran lapangan (2014)

Secara umum, sebagian besar penelitian mempunyai kedalaman airtanah yang sedang (2 - $4 \mathrm{~m})$ yang menempati luasan sekitar 51,4\% dari total luas daerah penelitian, yang sebagian besar menempati bentuklahan Beting Gisik (26,6\%) dan Dataran Alluvial $(15,5 \%)$. Sementara itu, daerah dengan kedalaman muka airtanah kurang dari 2 meter hanya menempati luasan kurang dari 5\% dari total wilayah kajian. 


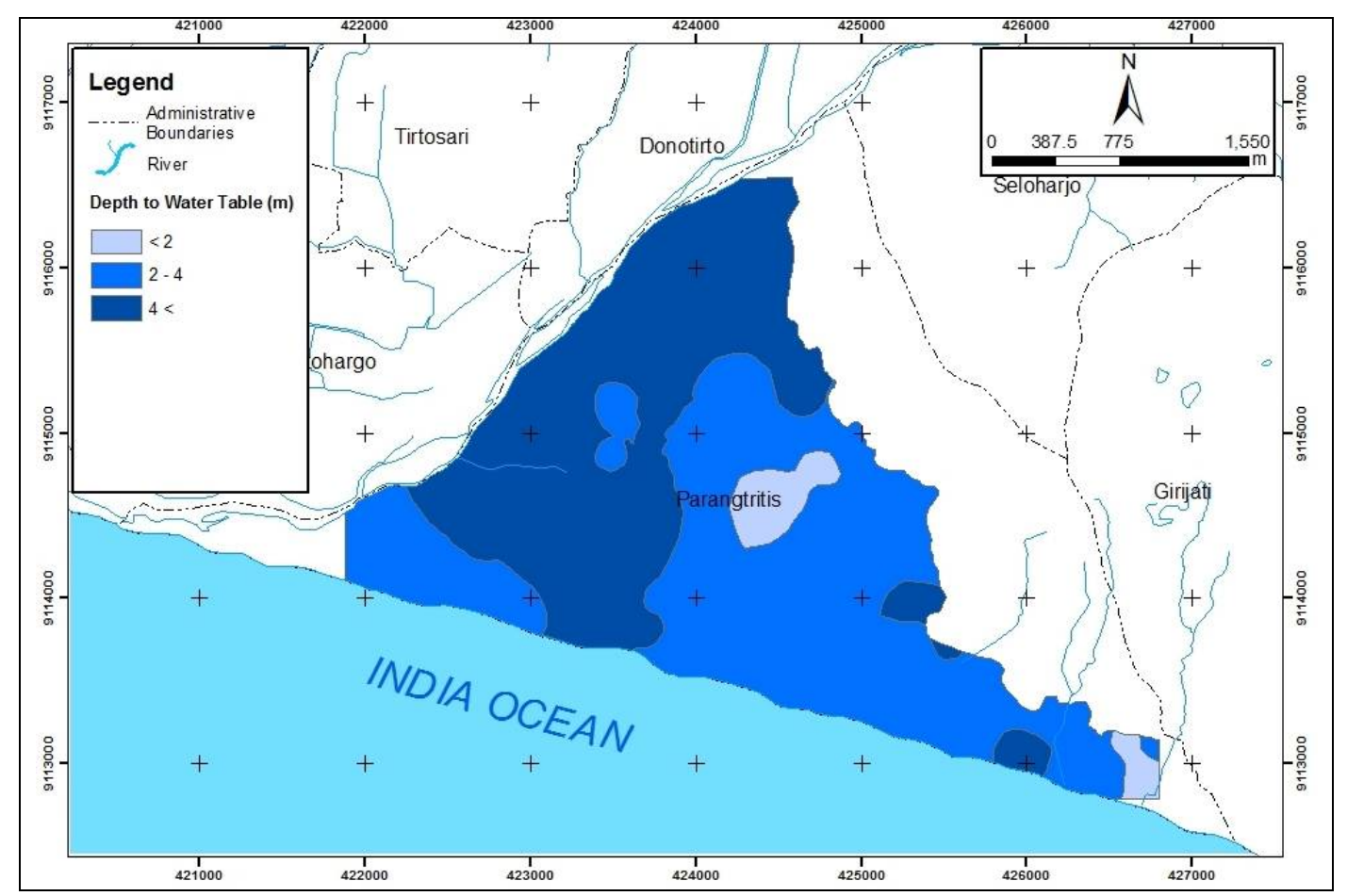

Gambar 3.2. Distribusi kedalaman muka airtanah di daerah penelitian

\subsection{Ketebalan Akuifer}

Sebelum dijabarkan ketebalan akuifernya, ada baiknya kita uraikan dulu hidrostratigrafi akuifer di daerah penelitian. Hidrostratigrafi akuifer mencakup kajian mengenai kondisi akuifer secara vertikal, dimana dengan mengetahui hidrostratigrafi maka akan dapat diketahui karakteristik akuifer, termasuk kondisi airtanah yang ada didalamnya. Didalam melakukan investigasi ini, digunakan metode Electrical Resistivity Tomography (ERT). Metode ini menekankan pada nilai hambatan $(\rho)$ untuk dapat menentukan material atau kondisi apa yang ada dibawah permukaan. Data yang digunakan merupakan data sebaran nilai resistivity secara vertikal pada setiap titik pengamatan, selanjutnya untuk dapat mengetahui kondisi hidrostratigrafi secara wilayah, maka digunakan metode crosssection. 
a. Cross-section G10-G11-G12

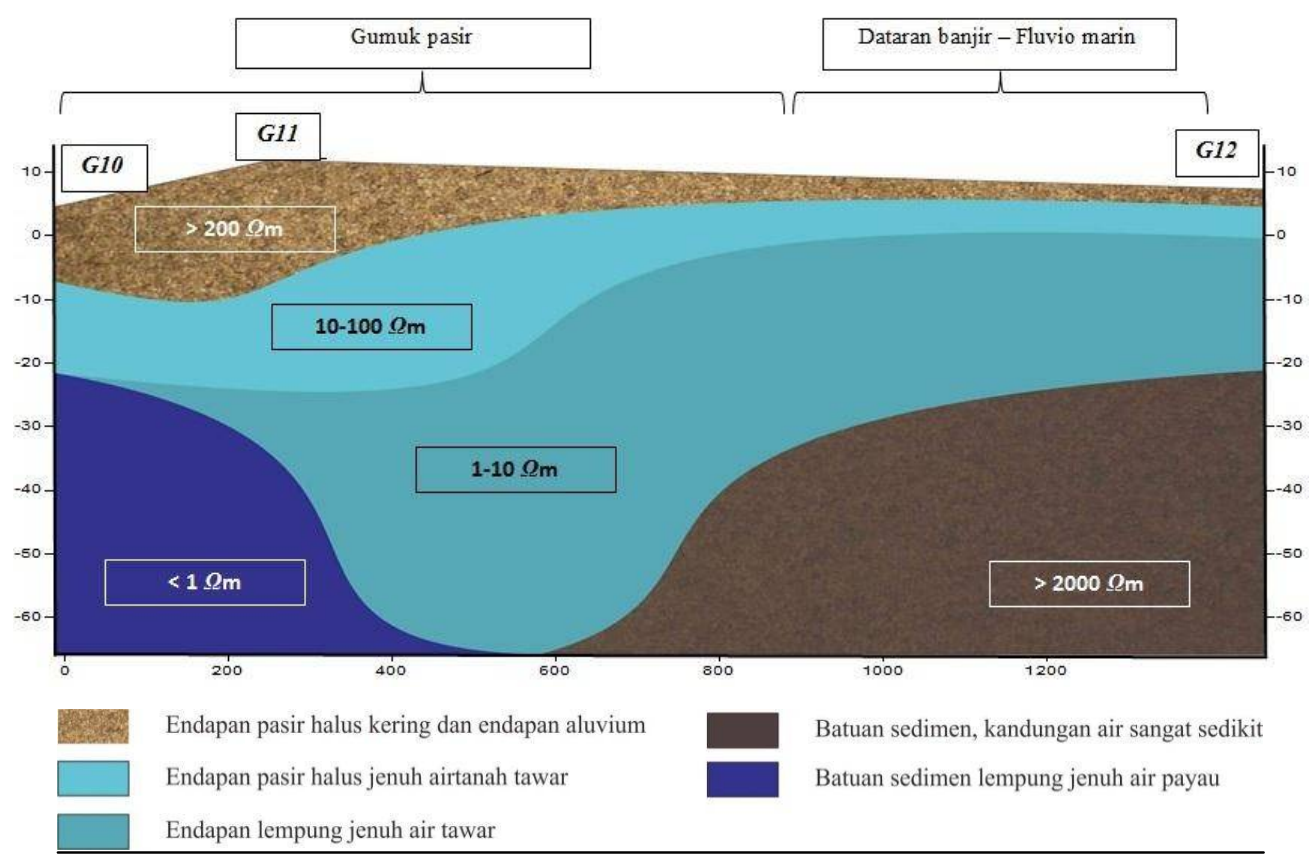

Gambar 3.3. Model Cross-section Jalur G10-G11-G12

Jalur pengamatan G10-G11-G12 (Gambar 3.3) terbentang sejauh 1393 meter dari arah utara-selatan. Lapisan teratas dari model stratigrafi adalah endapan pasir halus kering dan endapan aluvium dimana terdapat hingga kedalaman 5 meter dari permukaan tanah. Material berikutnya adalah pasir halus yang jenuh akan airtanah tawar, dengan kedalaman bervariasi dari 3- 10 meter dari permukaan tanah. Tebal material endapan pasir jenuh airtanah pada bentuklahan gumuk pasir lebih lebal daripada di bentuklahan dataran banjir dan fluvio-marin. Wilayah dengan bentuklahan dataran banjir dan fluvio marin lebeih didominasi oleb material endapan lempung jenuh airtanah yang terdapat pada kedalaman sekitar 2-3 meter dari permukaan tanah. terdapat indikasi adanya intrusi airlaut di titik G10 dengan kedalaman 20 meter, hal ini ditandai dengan adanya nilai resistivity yang relatif rendah yaitu $<1 \Omega \mathrm{m}$, dimana kemungkinan air bersifat payau. Di kedalaman 20 meter pada bentuklahan dataran banjir dan fluvio-marin terdapat material dengan nilai resistivity > $2000 \Omega \mathrm{m}$, hal ini mengindikasikan adanya batuan yang tidak mengandung airtanah. Kemungkinan material tersebut bersifat impermeabel atau massif sehingga tidak terdapat pori-pori untuk dapat menyimpan air. 


\section{b. Cross-section G6-G7-G8}

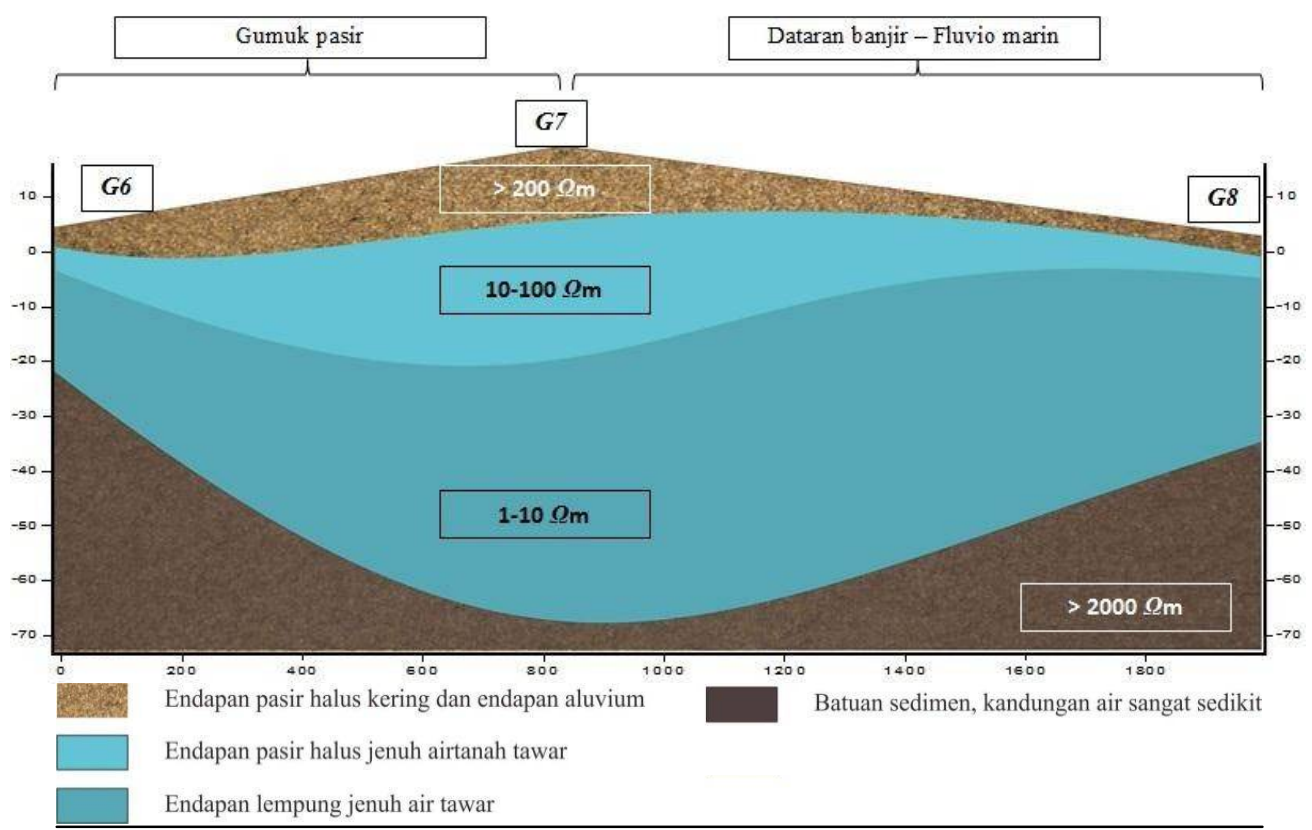

Gambar 3.4. Model Cross-section Jalur G6-G7-G8

Jalur pengamatan G6-G7-G8 (Gambar 3.4.) terbentang sejauh 1888 meter dari arah utara-selatan. Jalur ini melintasi dua bentuklahan yaitu bentuklahan dataran banjir dan dataran fluvio marin di sebelah utara, dan gumuk pasir di sebelah selatan. Hasil model hidrostratigrafi menunjukkan adanya simpanan airtanah tawar pada kedalaman 2-4 meter dari permukaan tanah. simpanah airtanah terebut berada pada material pasir halus. Di posisi yang lebih dalam terdapat pula akumulasi airtanah tawar yang terdapat pada material lempung mulai dari kedalaman 10 hingga 20 meter dari permukaan tanah. berada di posisi paling bawah, terdapat material batu pasir yang tidak jenuh airtanah. Material ini terdapat cukup luas, dari bentuklahan gumuk pasir hingga dataran banjir dan dataran fluvio-marin.

\section{c. Cross-section G2-3-4}

Berada di posisi yang paling barat, yaitu jalur pengamatan G2-G3- G4 (Gambar 3.5.) yang membentang sejauh 1308 meter dari arah utara-selatan. Jalur ini melintasi bentuklahan beting gisik dan dataran banjir dan fluvio-marin. Hasil interpretasi pada model hidrostratigrafi menunjukkan adanya simpanan airtanah tawar yang cukup besar yang terdapat dekat dengan titik G4. Simpanan airtanah tawar ini terdapat dari kedalaman $3-60$ meter di bawah permukaan tanah dan terdapat pada material pasir halus. 
Sementara itu di bawah lapisan pasir halus jenuh airtanah terdapat material lempung yang juga jenuh akan airtanah.

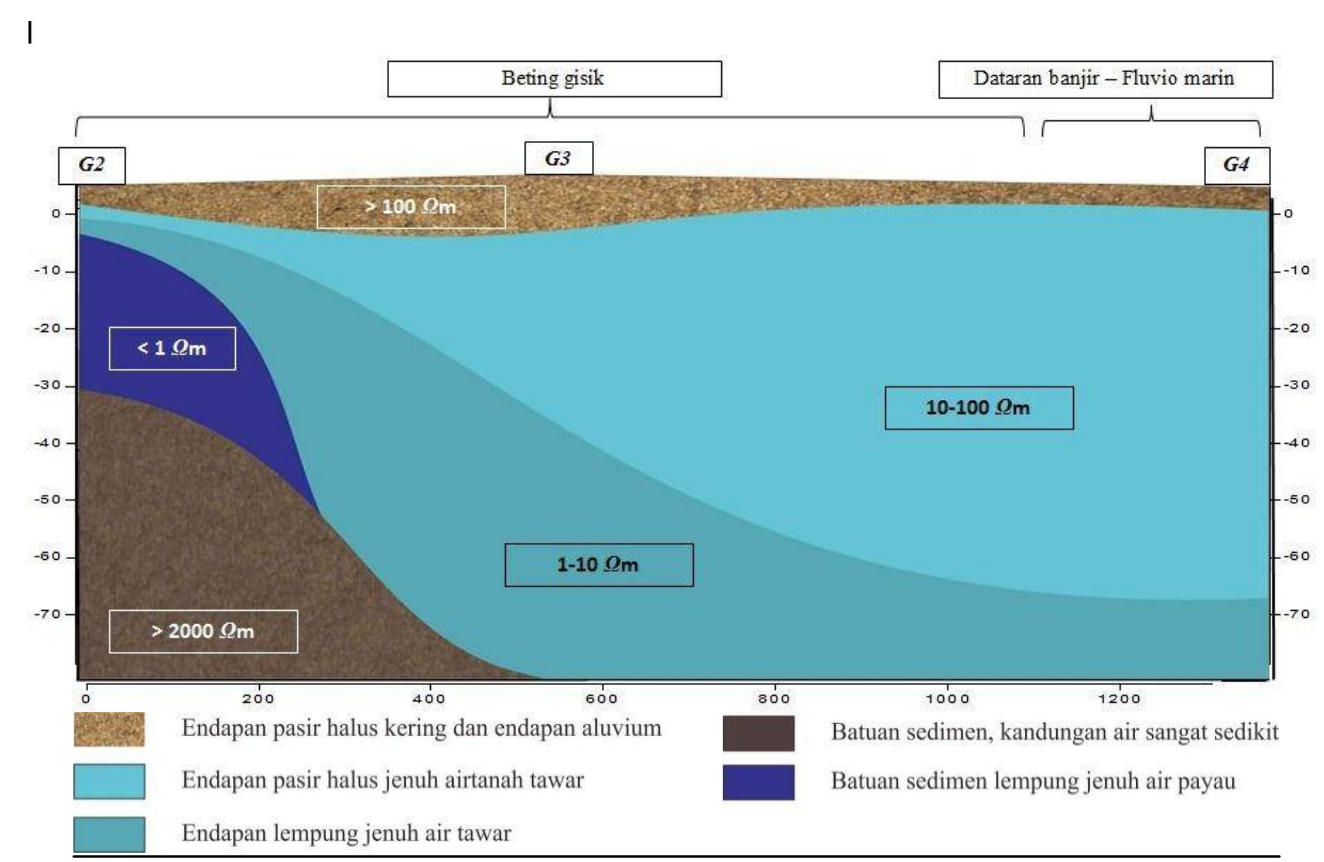

Gambar 3.5. Model Cross-section Jalur G2-G3-G4

Pola tebal airtanah dari titik G4 menuju titik G2 mengalami penurunan, dimana dari titik G4 berangsur-angsur menipis hingga pada titik G2 yang hanya memiliki ketebalan sekitar 4 meter. Dekat dengan titik G2 terdapat indikasi adanya intrusi air laut dimana ditandai dengan nilai resistivity yang cukup rendah $(\rho<1 \Omega \mathrm{m})$. Kondisi ini kemungkinan disebabkan oleh adanya aktivitas manusia dalam menurap airtanah yang kemudian berdampak pada pergerakan zona interface menuju ke arah daratan.

Berdasarkan hasil pemodelan hidrostratigrafi pada jalur G10-G11-G12, G6-G7-G8 dan GG2-G3-G4 dapat disimpulkan bahwa material penyusun akuifer di kawasan pesisir Parantritis didominasi oleh pasir halus dan lempung. kondisi ini sesuai dengan tipologi pesisir Parangtritis yang termasuk kedalam jenis marine depositional coast sehingga material pasir merupakan material yang umum dijumpai. Eksistensi material lempung berasal dari aktivitas fluvial Sungai Opak yang bermuara di sebelah barat Pantai Depok. Dari ketiga jalur pengamatan dapat ditemukan adanya material lempung yang berada di bawah material pasir, eksistensi lempung ini berfungsi sebagai penampung airtanah dna mencegah airtanah untuk lolos lebih jauh kedalam tanah. kondisi ini dapat dianalogikan 
bahwa bentuk akuifer di pesisir Parangtritis ini memiliki bentuk sepertii sebuah mangkok terbuka, dimana material lempung berfungsi sebagai penampung atau lapisan impermeabel. Hidrostratigrafi akuifer menunjukkan bahwa bentuk akuifer di kawasan pesisir Parangtritis ini berbentuk seperti sebuah mangkuk yang terbuka, dengan demikian maka polutan yang masuk kedalam sistem akuifer akan terus terjebak didalamnya karena tidak adanya aliran airtanah ke tempat lain.

Distribusi spasial ketebalan akuifer di daerah penelitian yang diwakili dengan 16 titik pendugaan geolistrik dengan metode VES, dan kemudian dibuat cross section-nya, slenajutnya dibagi menjadi 3 kelas ketebalan yaitu: (1) tipis (0 - 30 meter), (2) sedang (30$60 \mathrm{~m}$ ), dan (3) tebal (604 meter). Distribusi spasial ketebalan akuifer di daerah penelitian disajikan pada Gambar 3.6.

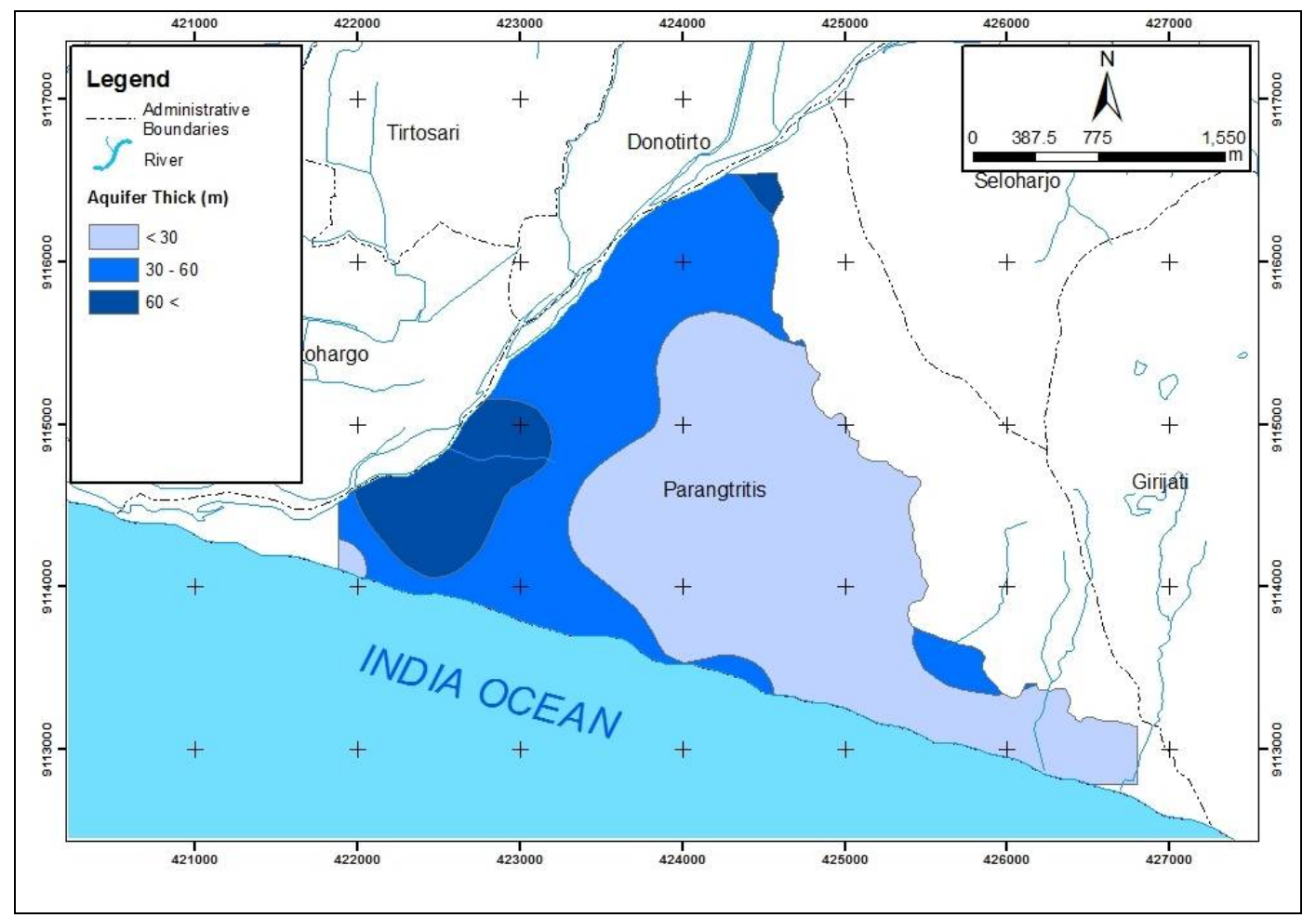

Gambar 3.6. Distribusi ketebalan akuifer di daerah penelitian

Secara umum, sebagian besar daerah penelitian memiliki akuifer tipis (0- 30 meter), yang menempati luasan sekitar sekitar 57\% dari seluruh daerah penelitian, yang mayoritasnya terletak pada satuan bentuklahan Beting Gisik (26,6\%) dan Dataran Alluvial $(22,1 \%)$. Akuifer dengan ketebalan tinggi hanya menempati luasan sekitar $10 \%$ dari total wilayah kajian. 


\subsection{Daya Hantar Listrik - DHL (parameter kualitas air)}

Berdasarkan pengukuran dari 90 sumur gali, nilai DHL di daerah penelitian bervariasi antara 165 dan $4790 \mu \mathrm{mhos} / \mathrm{cm}$. Nilai DHL kemudian diklasifikasikan menjadi tiga kelas, yaitu. (1) tawar (0 - 500 mikrodetik / cm), (2) sedang $(500-1000 \mu \mathrm{mhos} / \mathrm{cm})$, dan (3) tercemar (> $1000 \mu \mathrm{mhos} / \mathrm{cm}$ ). Distribusi spasial kondisi DHL kemudian disajikan pada Gambar 3.7.

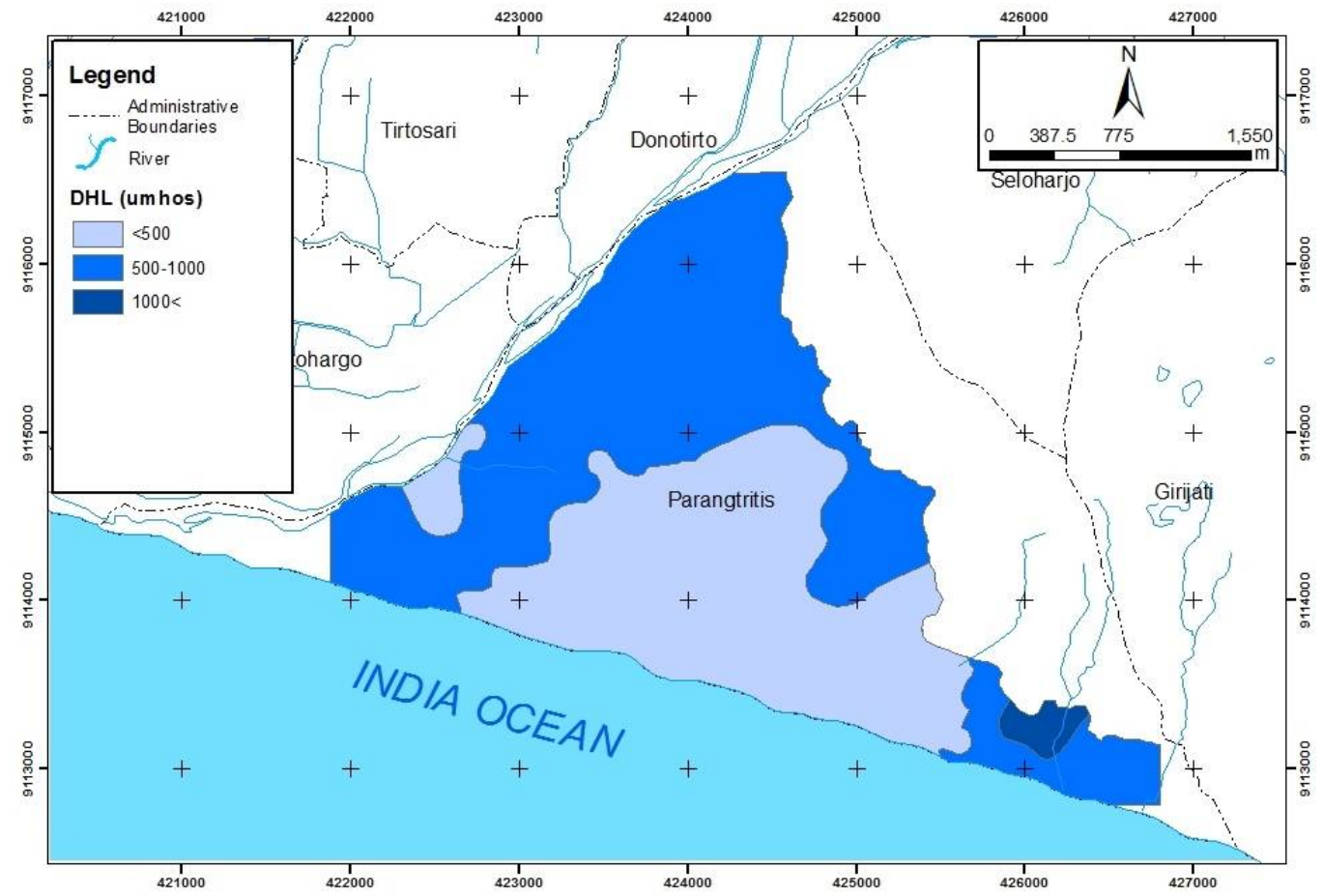

Gambar 3.7. Distribusi DHL di daerah penelitian

Berdasarkan Gambar 4, tampak bahwa wilayah studi didominasi oleh wilayah dengan kelas DHL tercemar (>1000 $\mu$ mhos/cm), yang meliputi cakupan luasan sekitar $54,7 \%$ yang sebagaian besar terletak di bentuklahan Dataran Alluvial. Sementara itu airtanah yang tawar umumnya terletak di bentuklahan Beting Gisik di sebelah selatan Dataran Aluvial yang menempati luasan sekitar $27,5 \%$ dari total wilayah kajian. 


\subsection{Zonasi potensi airtanah}

Peta akhir yang merupakan zonasi terpadu dari 3 peta tematik parameter airtanah disajikan pada Gambar 3.8. yang merupakan visualisasi dari skor total hasil overlay yang mempunyai variasi nilai antara 4,4 - 10,0, yang diklasifikasikan ke dalam tiga zona untuk mewakili potensi airtanah secara spaial. Klasifikasi potensi airtanah dikatetegorikan sebagai berikut: Potensi baik ( skor > 8,0), potensi sedang (skor 6,0-8,0), dan potensi miskin airtanah (skor <6.0). Kelas potensi airtanah baik berasal dari kombinasi skor tinggi pada 3 parameter lapangan (kedalaman muka airtanah dangkal, akuifer yang tebal, dan DHL yang rendah), dan jika paramaternya menunjukkan nilai berkebalikan maka potensi airtanahnya dikategorikan sebagai miskin. Sebenarnya tidak ada klasifikasi potensi tertentu yang mengategorikan airtanah pada kondisi sedang atau miskin, sebagaimana yang diungkapkan oleh Saraf dan Choudhury (1997) dan Preeja et al. (2010). Klasifikasi kelas potensi ini lebih tergantung pada keahlian dan pengetahuan peneliti pada wilayah kajian.

Dari seluruh luasan wilayah kajian yang diteliti, mayoritas potensi airtanah tergolong pada kelas baik $(49,8 \%)$ dan sedang $(48,7 \%)$. Sementara itu, kelas miskin airtanah hanya menempati luasan yang sangat kecil, yaitu hanya $1,5 \%$ dari total luas wilayah kajian. Potensi airtanah tersebut juga disajikan sebarannya pada satuan bentuklahan di daerah penelitian sebagaimana yang disajikan pada Tabel 3.2. dan Tabel 3.3.

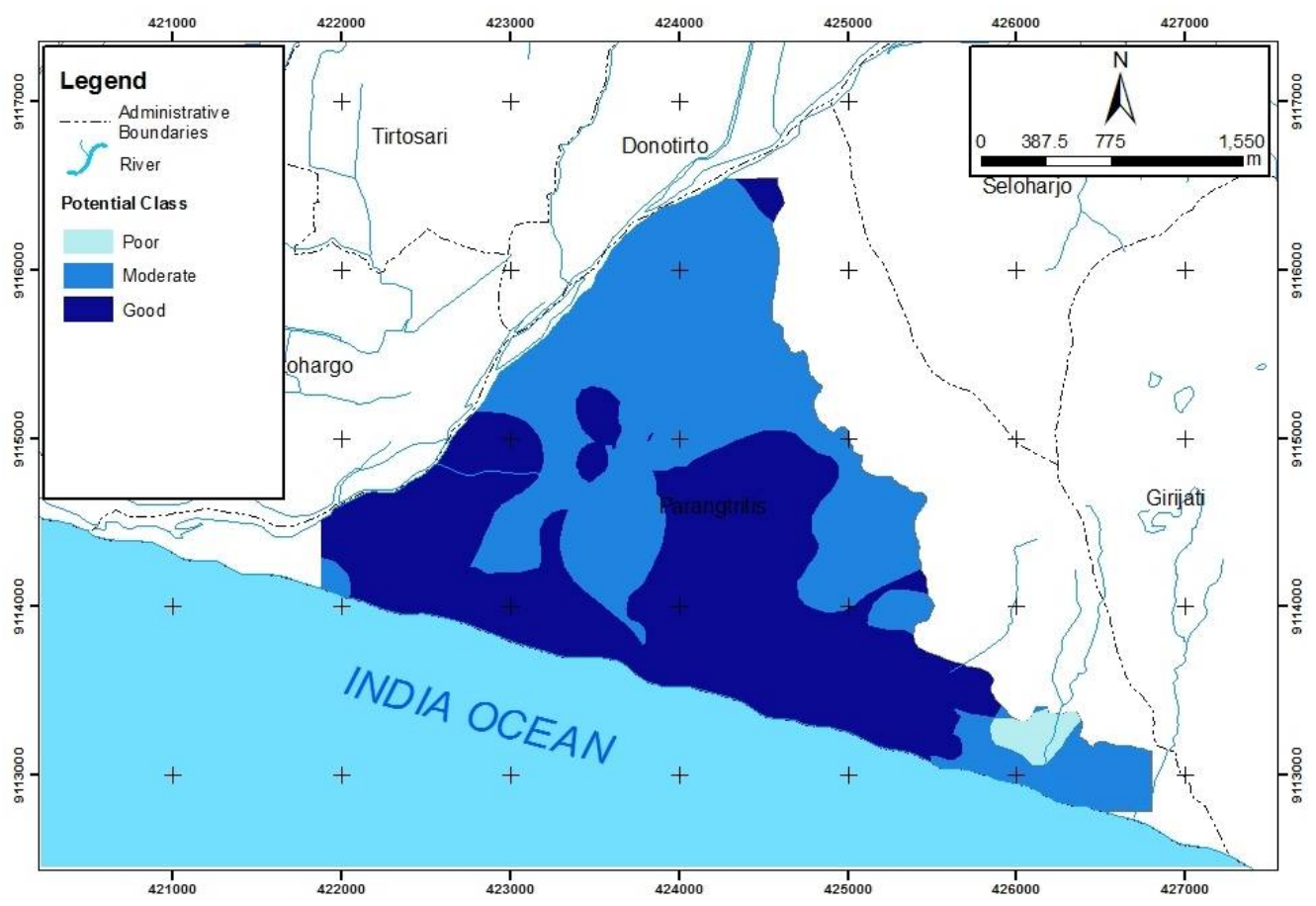

Gambar 3.8. Zonasi potensi airtanah daerah penelitian 
Tabel 3.2. Prediksi Potensi Zonasi Airtanah di Daerah Penelitian

\begin{tabular}{|c|c|c|c|}
\hline No & Kelas potensi & Bentuklahan & Luas (\%) \\
\hline \multirow{6}{*}{1} & \multirow{6}{*}{ Baik } & Dataran aluvial & 11.0 \\
\hline & & Pantai & 3.1 \\
\hline & & Beting Gisik & 30.4 \\
\hline & & Dataran Banjir & 0.3 \\
\hline & & Gumuk Pasir & 5.0 \\
\hline & & Subtotal baik & 49.8 \\
\hline \multirow{6}{*}{2} & \multirow{6}{*}{ Moderat } & Dataran aluvial & 34.0 \\
\hline & & Pantai & 1.0 \\
\hline & & Beting Gisik & 12.6 \\
\hline & & Dataran Banjir & 0.2 \\
\hline & & Gumuk Pasir & 0.9 \\
\hline & & Subtotal moderat & 48.7 \\
\hline \multirow{7}{*}{3} & \multirow{7}{*}{ Miskin } & Dataran aluvial & 0.0 \\
\hline & & Pantai & 0.0 \\
\hline & & Beting Gisik & 1.5 \\
\hline & & Dataran Banjir & 0.0 \\
\hline & & Gumuk Pasir & 0.0 \\
\hline & & Subtotal miskin & 1.5 \\
\hline & & Jumlah & 100.0 \\
\hline
\end{tabular}

Tabel 2 menunjukkan bahwa daerah yang berpotensi airtanah baik menempati luasan sebesar $49,8 \%$. Luasan ini tidak terpaut jauh dibanding persentase luasan zona potensi airtanah sedang (48,7\%). Satuan bentuklahan Beting Gisik mendominasi zona potensi airtanah baik (30,4\%), sedangkan zona potensi airtanah sedang mayoritasnya dijumpai pada Dataran Aluvial (34,0\%). Selanjutnya, jika ditinjau sebarannya menurut satuan bentuklahannya, maka sebagian besar Dataran Aluvial termasuk pada zone dengan airtanah sedang (34\%) dan hanya $11 \%$ yang masuk ke dalam zona potensi airtanah baik. Faktor penghambat utama bentuklahan Dataran Aluvial ini masuk pada zone potensi airtanah baik adalah nilai DHL yang tinggi yang disebabkan materialnya yang sangat halus sehingga kesempatan kontak antara air dan batuan menjadi lama yang meningkatkan nilaiDHL dalam air. Selanjutnya, daerah yang berpotensi airtanah sedang mayoritasnya menempati bentuklahan Dataran Aluvial (34\%) yang kemudian disusul oleh Beting Gisik (12,6\%). 
Tabel 3.3. Prediksi Potensi Zonasi Airtanah Sesuai Dengan Unit Bentuklahan di Daerah Penelitian

\begin{tabular}{|c|c|c|c|c|c|}
\hline \multirow{2}{*}{ No } & \multirow{2}{*}{ Bentuklahan } & \multicolumn{3}{|c|}{ Luas per Kelas potensi (\%) } & \multirow{2}{*}{$\begin{array}{c}\text { Luas } \\
(\%)\end{array}$} \\
\hline & & Baik & Sedang & Miskin & \\
\hline 1 & $\begin{array}{l}\text { Dataran } \\
\text { aluvial }\end{array}$ & 11.0 & 34.0 & 0.0 & 45.0 \\
\hline 2 & Pantai & 3.1 & 1.0 & 0.0 & 4.1 \\
\hline 3 & Beting Gisik & 30.4 & 12.6 & 1.5 & 44.5 \\
\hline 4 & $\begin{array}{l}\text { Dataran } \\
\text { Banjir }\end{array}$ & 0.3 & 0.2 & 0.0 & 0.5 \\
\hline \multirow[t]{2}{*}{5} & Gumuk Pasir & 5.0 & 0.9 & 0.0 & 5.9 \\
\hline & & & & Jumlah & 100.0 \\
\hline
\end{tabular}




\section{BAB IV. KESIMPULAN}

Jika dilihat per satuan bentuklahan, Dataran Aluvial yang menempati $45 \%$ dari total luasan daerah penelitian, mayoritasnya mempunyai potensi airtanah sedang (34\%) dan potensi baik (11\%) dan tidak mempunyai daerah yang miskin airtanahnya. Bentuklahan Pantai (Beach) sebagian besar masuk pada kelas potensi airtanah baik $(3,1 \%)$ dan sedang (1\%) dan juga tidak memiliki daerah yang miskin airtanahnya. Sementara itu, bentuklahan Beting Gisik mempunyai persentase yang tinggi potensi airtanah baiknya yaitu sebesar $(30,4 \%)$, yang disusul dengan potensi sedang $(12,6 \%)$ dan miskin $(1,5 \%)$. Pada Dataran Banjir dan Gumuk Pasir, potensi airtanah yang dominan adalah baik (0,3\% dan 5\%), dan pada kedua bentuklahan ini tidak dijumpai kelas miskin airtanah.

\section{DAFTAR PUSTAKA}

Adji, T.N., 2003, Studi Pemodelan Recharge Airtanah Tahunan Kotamadya Yogyakarta, Lembaga Penelitian UGM

Adji, T.N., 2007, Application of Water Table Fluctuation Method to Quantify Spatial Groundwater Recharge Within the Southern Slope of Merapi Volcano, Indonesia, Indonesian Journal of Geography, Vol. 39:2

Adji, T.N., Noordianto, M.H. 2006. A Discussion of Groundwater Deterioration by Means of Its Recharge Within The Southern Part of Merapi Volcano, Proceeding of International Interdisciplinary Conference-Volcano International Gathering, 2006, 4-10 Sept 2006ISSN 979-8918-53-3

Adji, T.N., Sejati, S.P., 2014, Identification of Groundwater Potential Zones Within an Area with Various Geomorphological Unit by Using Several Field Parameters and GIS Approach in Kulon Progo Regency, Java, Indonesia, Arabian Journal of Geoscience, Vol 1 (7), p.161-172

Appelo, C.A.J., Postma, D., 1994. Geochemistry, groundwater and pollution. A.A. Balkema, Rotterdam, 536p.

Bemmelen, R.W. van, 1970. The Geology of Indonesia. General Geology of Indonesia and Adjacent Archipelagoes. Government Printing Office. The Haque

Bobba, A. G., Bukata, R. P., Jerome, J. H., 1992. Digitally processed satellite data as a tool in detecting potential groundwater flow systems, Journal of Hydrology, 131(1-4), $25-62$.

Edet, A.E., Okereke, C.S., 1997. Assessment of hydrogeological conditions in basement aquifers of the Precambrian Oban massif, southeastern Nigeria, Journal of Applied Geophysics, 36, 195204.

Engman, E. T., Gurney, R. J.,1991. Remote Sensing in Hydrology. London: Chapman and Hall.

Meijerink, A.M.J., 2000, Groundwater. In G. A. Schultz \& E.T. Engman (Eds.), Remote sensing in hydrology and water management (pp. 305-325). Berlin: Springer.

Moscow State University, 2001. IP2WIN Version 2.1., IP_Res2, IP_Res3, User's Guide, Moscow

Nagarajan, M., Singh, S., 2009. Assessment of groundwater potential zones using GIS technique, Journal Indian Society of Remote Sensing, 37:69-77

Prashasti , A., Maneesh, S., Shakti, S., Dheer, S., 2011. Landform analysis and classification with GIS and Remote Sensing- a micro level study, International Journal of Earth Sciences and Engineering, Volume 04: pp 330-333, ISSN 0974-5904 
Preeja, K. R., Joseph, S., Thomas, J.,Vijith, H., 2010. Identification of Groundwater Potential Zones of a tropical river basin (Kerala, India) using remote sensing and GIS techniques, Journal Indian Society of Remote Sensing, DOI 10.1007/s12524-011-0075-5

Rai, B., Tiwari, A., Dubey, V.S., 2005. Identification of groundwater prospective zones by using remote sensing and geoelectrical methods in Jharia and Raniganj coalfields, Dhanbad district, Jharkhand state, Journal of Earth System Science, 114, No. 5,

Rao, D.P., 2002. Remote sensing application in geomorphology, Tropical Ecology 43(1): pp 49-59, ISSN 0564-3295

Rao, V.B., Briz-Kishore, B.H., 1991. A methodology for locating potential aquifers in a typical semiarid region in India using resistivity and hydrogeologic parameters, Geoexploration, 27, 5564.

Rose-Suja, R.S, Krishnan, N., 2009. Spatial analysis of groundwater potential using remote sensing and GIS in the Kanyakumari and Nambiyar Basins, India, Journal Indian Society of Remote Sensing, 37:681-692

Santosa, L.W., Adji, T.N., 2014, Karakteristik Akuifer dan Potensi Airtanah Graben Bantul, Gadjah Mada University Press, 299 p., Jogjakarta

Santosa, L.W., Adji, T.N., 2006, Pendugaan Geolistrik Untuk Identifikasi Keterdapatan Airtanah di Perkebunan Kelapa Sawit Muarakandis Kabupaten Musirawas Provinsi Sumatera Selatan, Majalah Geografi Indonesia, Vol. 20:2

Saraf, A. K. and Choudhury, P. R., 1997. Integrated Application of Remote Sensing and GIS Groundwater exploration in hard rock terrain, Proceedings. Int. Symp. on Emerging trends in Hydrology, Department of Hydrology, Roorkee, September 25-27, 1997, Vol. I, 435-442.

Saraf, A. K., Choudhury, P. R., 1998. Integrated remote sensing and GIS for groundwater exploration and identification of artificial recharge sites, International Journal of Remote Sensing. 19(10), 1825-1841.

Scaramuzza, P., Micijevic, E. And Chander, G., 2004, SLC gap-filled products: Phase one methodology. Available online at: http://landsat.usgs.gov/data products/slc off data products/documents/SLC Gap Fill Methodology.pdf

Sejati, S.P., Adji, T.N., 2013, Kajian Potensi Airtanah Di Lereng Selatan Gunungapi Merapi untuk Mencukupi Kebutuhan Air Domestik pada Hunian Sementara, UGM

Shahid, S., Nath, S.K., 2002. GIS integration of remote sensing and electrical sounding data for hydrogeological exploration, Journal of Spatial Hydrology, Vol.2 No.1

Yeh, H.S., Lee, C.H., Hsu, K.C., Chang, P.H., 2009. GIS for the assessment of the groundwater recharge potential zone, Environmental Geology, 58:185-195 
